\title{
Growth of Shorea contorta Vid. Inoculated with Eucalypt Ectomycorrhizal Fungi in the Nursery and in a Logged-Over Dipterocarp Forest in Surigao, Philippines
}

\author{
Nelly S. Aggangan ${ }^{1 *}$, Mitzi Ann T. Pollisco², Jeremias B. Bruzon ${ }^{3}$, Joan S. Gilbero ${ }^{3}$ \\ ${ }^{1}$ National Institute of Molecular Biology and Biotechnology, University of the Philippines Los Baños, College, Philippines; ${ }^{2}$ Eco- \\ systems Research and Development Bureau, Department of Environment and Natural Resources, Los Baños, Philippines; ${ }^{3}$ Depart- \\ ment of Environment and Natural Resources, Ecosystems Research and Development Services, Surigao City, Philippines. \\ Email: *nelly_aggangan@yahoo.com
}

Received February $29^{\text {th }}, 2013$; revised April 1 ${ }^{\text {st }}, 2013$; accepted April $9^{\text {th }}, 2013$

Copyright (C) 2013 Nelly S. Aggangan et al. This is an open access article distributed under the Creative Commons Attribution License, which permits unrestricted use, distribution, and reproduction in any medium, provided the original work is properly cited.

\begin{abstract}
This study was conducted to determine the compatibility of ectomycorrhizal (ECM) fungi associated with eucalypts on dipterocarps. Two nodal cuttings of Shorea contorta (Vid.) were rooted in a non-mist system for two months, and later inoculated with vegetative mycelia of three strains of Pisolithus collected under eucalypts and a strain of Scleroderma from dipterocarps. Inoculated rooted cuttings were planted in irradiated potting mix and raised in the nursery for five months. Root colonization prior to outplanting ranged from 31\% to $38 \%$ and ECM fungi did not colonize the uninoculated ones. The cuttings were outplanted in a logged-over dipterocarp forest in Bislig, Surigao Sur following a Randomized Complete Block Design with four blocks; each block was planted with 50 seedlings. Two years after outplanting, Pisolithus strain from New Caledonia (H6394) promoted the highest height $(46 \mathrm{~cm})$ and diameter $(0.48 \mathrm{~cm})$ increment. Height was increased by $17 \%$ and diameter by $7 \%$ relative to the uninoculated control. By contrast, Pisolithus strain from the Philippines (H615) gave the shortest $(26 \mathrm{~cm})$ height increment and smallest $(0.42 \mathrm{~cm})$ diameter. Diameter growth of cuttings inoculated with Scleroderma D01 (from the Philippines) and a Pisolithus strain from Australia (H445) was bigger $(0.47 \mathrm{~cm})$ than the uninoculated treated cuttings $(0.45 \mathrm{~cm})$. In terms of survival, the uninoculated cuttings gave the highest $(90 \%)$ percent survival while the lowest $(60 \%)$ was those inoculated with Pisolithus strain from New Caledonia. It is possible that the indigenous ECM fungi infected easily the roots of the uninoculated cuttings thus contributing to the high survival rate $(90 \%)$. During outplanting, fruit bodies of $S$. columnare were present in the field site. The results, however, show that ECM fungi were able to colonize the roots and that some strains promoted the growth and survival of $S$. contorta planted in a logged-over dipterocarp forest in Bislig, Surigao, Philippines.
\end{abstract}

Keywords: Ectomycorrhiza; Pisolithus; Scleroderma; White Lauan; Rooted Cuttings

\section{Introduction}

The lowland dipterocarp forests of Southeast Asia including Malaysia, Indonesia and the Philippines, are dominated by trees belonging to the family Dipterocarpaceae. They are of considerable environmental and economic value at the local, regional and global scale, providing many goods and services to a growing population [1]. The forests of this region are among the fastest disappearing in the world and restoration is urgently required. The importance of species-site matching, mycorrhizal fungi and post-planting maintenance for restoration are apparent [1].

"Corresponding author.
Dipterocarpaceae consist of 17 genera and approximately 500 species worldwide and the largest genera are Shorea (196 species), Hopea (104 species), Dipterocarpus (70 species), and Vatica (65 species) [2,3]. Shorea contorta Vid. (white lauan) is one of the most important dipterocarp species because of its economic value and fast growth. Dipterocarp trees are reported to be strictly associated with ectomycorrhizal (ECM) fungi [4-8]. The fungal species involved are Basidiomycetes and Ascomycetes [9]. These ECM fungi play important roles in nutrient and biogeochemical cycle in forest ecosystems $[9,10]$. Ectomycorrhizal fungi reported to be associated with dipterocarps are: Amanita, Boletus, Cantharellus, Russula, Lactarius, Laccaria and Scleroderma [4,11-15]. 
Many reports have shown that ECM fungi increase the growth and nutrient uptake of dipterocarps seedlings [16-18], can act as biological control against root pathogens [19] and increase drought tolerance [20].

Pisolithus and Scleroderma are the well-studied genera of ECM fungi and the most common in young plantations of pines, eucalypts and acacias in the Philippines. The spores of these ECM fungi are the components of Mycogroe tablets developed at the National Institute of Molecular Biology and Biotechnology (BIOTECH), University of the Philippines Los Baños (UPLB), College, Laguna, which are now commercially distributed in the country [21]. Under dipterocarps, Sclerodermas are relatively common but no Pisolithus so far was observed. Mycogroe tablets containing spores of Scleroderma and Pisolithus from pines and eucalypts were previously reported to increase growth of dipterocarps planted in a marginal grassland [15].

The function of ECM in promoting tree growth and survival in marginal sites depends on the compatibility of the host and the fungus [22]. It is therefore crucial to determine compatibility of ECM fungi on dipterocarps. Compatibility is defined as the merging of symbionts to form a structurally defined mycorrhiza in which physiological exchange of metabolites between the partners, improve nutrition of host plant and the fungus. In a compatible association, infected roots have a fungal mantle, a well-developed Hartig net and a radially elongated epidermal cells in the case of eucalypts [23]. On the other hand, signs of incompatibility include, the production of phenolics in root tissue and tissue disorganization which produces deleterious effects on the fungus or hosts or both [24].

Ectomycorrhizal plants vary widely in compatibility with ECM fungi [23] and the number of fungal associates differs strongly among ECM hosts [24]. Smits [4] and Becker [26] reported that ECM fungi of some dipterocarp species in Malaysia are restricted to single host species. Soil from beneath the ECM tree Dipterocarpus grandiflorus failed to provide ECM fungi for S. obtusa of the same family [4]. Likewise, S. leprosula and S. maxwelliana seedlings growing in the same vicinity only shared two of twenty ECM types [26].

The idea of inoculating dipterocarps with ECM fungi associated with eucalypts was based on the observation in Indonesia and in the Philippines that S. columnare was found underneath eucalypts and dipterocarps. Three species of the genus Pisolithus have been described from dipterocarp species. Pisolithus aurantioscabrosus has been reported from Malaysia under Shorea macroprera [27], P. adbitus collected under Dipterocarpus alatus in Thailand [28] and P. indicus associated with Vatica indica in India [29]. In the Philippines, no basidiome of
Pisolithus was ever observed under dipterocarps [12-14]. Since Pisolithus is cosmopolitan in both tropical and temperate regions and forms ECM association with wide range of woody plants, the aim of this study was to determine the growth performance of $S$. contorta rooted cuttings inoculated with three isolates of eucalypts' ECM fungus Pisolithus and a dipterocarps' Scleroderma isolate under nursery and in a logged-over dipterocarp forest in Bislig, Surigao City, in the island of Mindanao, Philippines.

\section{Materials and Methods}

\subsection{Experimental Design}

There were five inoculation treatments which was conducted following a Randomized Complete Block Design with five blocks in the nursery and four blocks in the field. Under nursery conditions, there were 100 plants per treatment. The nursery phase was conducted at the screenhouse of the National Institute of Molecular Biology and Biotechnology (BIOTECH), University of the Philippines Los Baños (UPLB) for five months and shipped to Surigao a month prior to outplanting. Each block contained ten seedlings planted in a row plot with a spacing of one meter and 2 meters in between plots.

\subsection{Field Site}

The site is located within the Dipterocarp Forest Research Center, Barangay Maharlika, Bislig, Surigao del Sur. The experimental area is about 0.30 hectare and it is contiguous with rolling terrain and elevation ranging from $100-200 \mathrm{~m}$ asl. The area is a second growth forest supporting lesser known tree species but dominated by dipterocarp trees with diameter ranging from 50 to $80 \mathrm{~cm}$. The climatic type is 4 (with no distinct dry and wet season). Maximum rainfall is from November to March. The average monthly rainfall is $3472 \mathrm{~mm}$, mean temperature is $24.5^{\circ} \mathrm{C}$ and mean relative humidity of $86 \%$. The soil is sandy clay loam with $\mathrm{pH}$ of $5.9,2.48 \%$ organic matter, $0.06 \%$ total nitrogen and $0.21 \mathrm{mg} \cdot \mathrm{kg}^{-1}$ available phosphorus.

\subsection{Production of Rooted Cuttings}

Cutting propagation as an alternate techniques for the mass production of genetically and phenotypically superior dipterocarp planting stocks has been practiced [30, $31]$. Rooted cuttings used in this experiment were produced at the Ecosystems Research and Development Bureau (ERDB), Department of Environment and Natural Resources (DENR), Los Banos, Laguna using two nodal cuttings technique of Pollisco [30]. Cuttings were obtained from a clonal hedge garden established near the 
ERDB building. Two nodal cuttings of $S$. contorta were rooted in a non-mist system for two months.

\subsection{ECM Production and Inoculation of Rooted Cuttings}

Cultures of Pisolithus H6394 from New Caledonia and H445 from Australia were provided by Dr. Bernie Dell of Murdoch University, Perth, Western Australia. Pisolithus H615 was collected in Bukidnon in the island of Mindanao, Philippines. The three Pisolithus isolates were associated with eucalypts. A local strain of Scleroderma (DO1) was collected from under dipterocarp forest growing in Zambales, Luzon. The four ECM fungi were mass produced and maintained at the National Institute of Molecular Biology and Biotechnology, University of the Philippines Los Baños, College, Laguna on a Modified Melin Norkran's (MMN) agar medium [32].

Rooted cuttings were inoculated with one-month old vegetative mycelia of three isolates of Pisolithus, and an isolate of Scleroderma. Mycelial disks (3 $\mathrm{cm}$ diameter) were placed in contact with the roots. The inoculated rooted cuttings were transplanted in 4" $\times 8$ " PE bags filled with irradiated potting mix 1:1:1 garden soil, sand and coir dust), raised for five months in the nursery where growth was monitored monthly. Each treatment consisted of 100 seedlings. The seedlings were later shipped to Mindanao. After one month of acclimatization, the seedlings were outplanted in a logged-over dipterocarp forest under the jurisdiction of the Dipterocarp Forest Research Center, Ecosystems Research and Development Services-DENR building, Bislig, Surigao Sur. Prior to outplanting, the initial height and stem diameter was measured.

\subsection{Plant Growth Measurement}

Height of nursery grown seedlings were measured prior to outplanting in the field. Height and diameter were measured at two, four and eight years after transplanting. Height was measured using a meter stick and later a bamboo stick at $10 \mathrm{~cm}$ above the soil surface up to the shoot tip. Diameter was measured using a vernier caliper and later using a diameter tape at $10 \mathrm{~cm}$ above the soil surface. Wood volume was calculated using the formula (Stan Rance, personal communication):

$$
\text { Wood volume }=\left(\text { DGLE }^{2} \times \text { Height } \times 3.1416\right) / 12
$$

where

DGLE (Diameter at ground level)

$=($ Diameter at $10 \mathrm{~cm}$ above the ground $\times$ Height $) /$

$$
\text { (Height }-10 \mathrm{~cm} \text { ) }
$$

Representative eight-year-old trees (height ranged from the smallest to the tallest) were harvested (cut 10 $\mathrm{cm}$ above the ground) at random covering the whole experimental plot similar to that done on eucalypts [33]. Wood volume of trees was computed using the equation derived from a regression analysis.

\subsection{Assessment of Mycorrhizal Infection}

Destructive sampling was done prior to shipping of dipterocarp seedlings. The root system of plants (5 seedlings per treatment) in the nursery was examined under a microscope for the presence of ectomycorrhizas. Root samples were also collected at two and eight years to assess root colonization by the inoculant fungi. Surface soil was scraped off using a hand trowel and fine roots $(0.3-0.5$ $\mathrm{m}$ away from the base of the tree) were detached from the main roots growing on two sides of randomly selected trees ( 2 trees per treatment per block). Preliminary examination of fresh collected fine roots indicated distinctive yellow Pisolithus mycorrhizas. Root samples were washed in water then later preserved in 50\% ethanol until these were cleared and stained with lactic-glycerol trypan blue [34]. Stained roots were spread evenly on Petri plates with grid lines and the presence or absence of ectomycorrhizas (fully colonized root tips) were recorded on roots that crossed the grid lines [35]. The presence of fruit bodies of ectomycorrhizal fungi was assessed after outplanting.

\subsection{Statistical Analysis}

Height, diameter and wood volume were analyzed statistically using an Analysis of Variance of a Randomized Complete Block Design [36]. Treatment means were compared using a Duncan Multiple Range Test at $p<$ 0.05 [37]. Statistical analysis was done using MSTATC computer program [38].

\section{Results}

\subsection{Mycorrhizal Root Colonization and Fruit Bodies of ECM Fungi}

Prior to outplanting, the roots tips were colonized (11\% $38 \%$ ) by ECM fungi (Figure 1). The uninoculated plants were not mycorrhizal. Two years after outplanting, root colonization by the different ECM fungi studied ranged from $11 \%$ to $38 \%$ and no ectomycorrhizal root tips was observed on the uninoculated plants.

During outplanting, fruit bodies of Scleroderma species were observed in the nursery close to the experimental area. Fruit bodies were sessile as well as stalked Sclerodermas most likely S. columnare. Eight years after outplanting, root samples collected from the root zone 

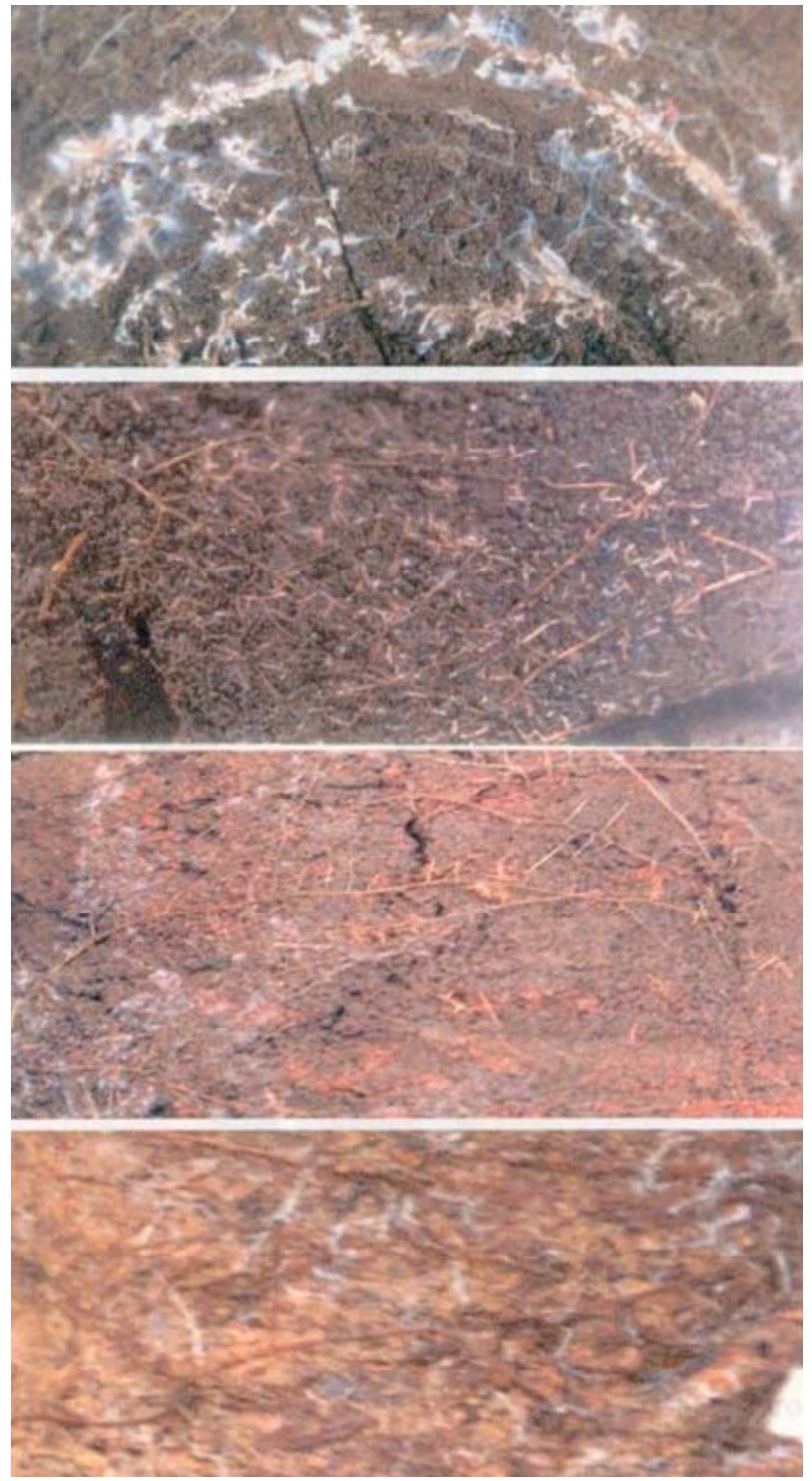

Figure 1. Roots of 6-month-old dipterocarp seedlings colonized by different ectomycorrhizal fungi prior to outplanting in a logged-over dipterocarp forest in Bislig, Surigao City, Mindanao Island, Philippines.

revealed that only those inoculated with the Philippine Pisolithus (H615) had mycorrhizal association. The roots were golden yellow and $10 \%$ to $20 \%$ of the root tips were colonized with Pisolithus H615.

\subsection{Seedling Growth and Mycorrhizal Colonization Prior to Outplanting}

Prior to outplanting, seedlings inoculated with a eucalypt Pisolithus strain from Australia (H445) and from New Caledonia (H6394) promoted the largest leaf size/area, greener and healthier than those inoculated with Philippine ECM fungus (H615) and much more with the uni- noculated control seedlings (Figure 2). By contrast, cuttings inoculated with Philippine Scleroderma (D01) isolate from dipterocarps and the Australian eucalypt $\mathrm{Pi}$ solithus gave the highest height increment (Figure 3). Height was increased by $22 \%$ and $20 \%$, respectively.

\subsection{Seedling Survival under Field Conditions}

The uninoculated plots gave the highest $(90 \%)$ seedling survival two years after outplanting (Figure 4(a)). By contrast, plots inoculated with the Australian Pisolithus H445 gave the lowest (63\%). Among the mycorrhizal plants, those inoculated with the New Caledonian Pisolithus H6394 gave a seedling survival of $83 \%$, Philippine Pisolithus of $70 \%$ and the dipterocarp Scleroderma of $67 \%$. Four years after outplanting, the uninoculated treatment had a great drop of the number of surviving plants from $90 \%$ at two years to $40 \%$ at four years after outplanting (Figure 4(b)). Seedlings inoculated with the Philippine Pisolithus gave the highest number of surviving seedlings (53\%). Eight years after outplanting, seedlings inoculated with the New Caledonian Pisolithus gave the lowest (13\%) survival while the Philippine Pisolithus and Scleroderma gave the highest with seedling survival of $37 \%$ and $40 \%$, respectively (Figure $4(\mathbf{c})$ ). The uninoculated treatment gave the second lowest $(23 \%)$

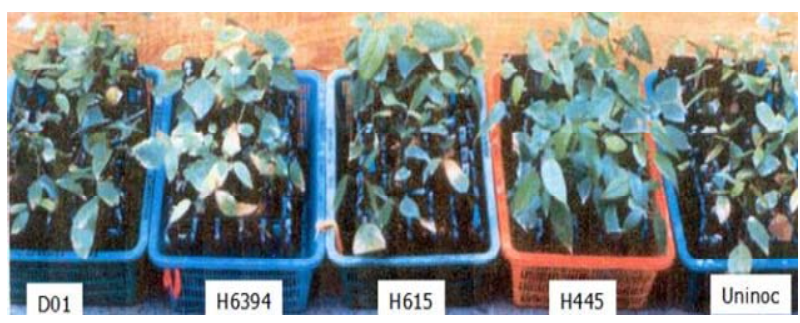

Figure 2. Six-month-old $S$. contorta rooted cuttings due to inoculation with three isolates of Pisolithus (H6394, H615, H445) and a Scleroderma (D01) isolates prior to outplanting in Bislig, Surigao, Mindanao.

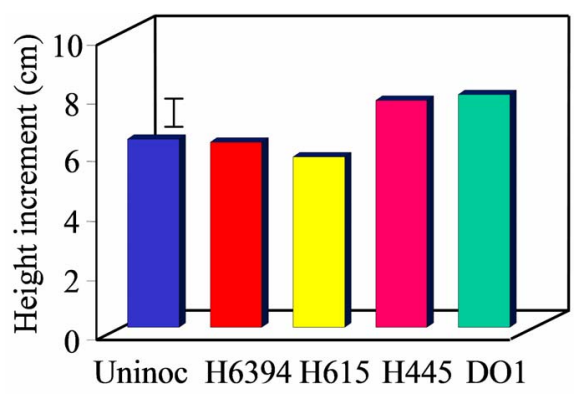

Figure 3. Height increment of six-month-old $S$. contorta rooted cuttings due to inoculation with three isolates of $\mathrm{Pi}$ solithus (H6394, H615, H445) and a Scleroderma (D01) isolates prior to outplanting in Bislig, Surigao, Mindanao island, Philippines. Bar represents LSD value at $p<0.05$. 

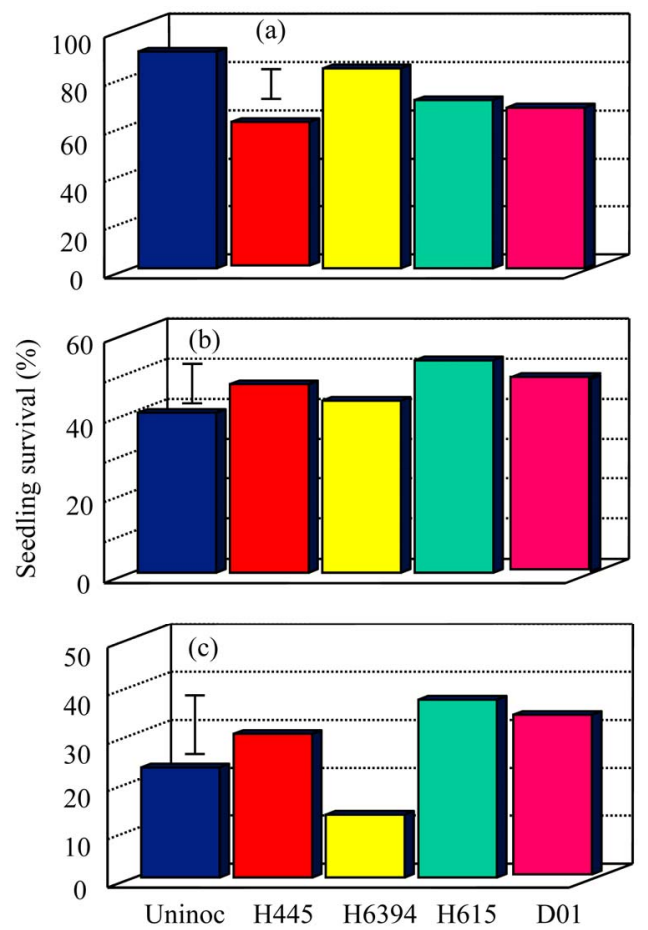

Figure 4. Seedling survival of $S$. contorta inoculated with eucalypt and dipterocarp ectomycorrhizal fungi Pisolithus (H445, H6394 and H615) and Scleroderma (D01) isolates 2 (a), 4 (b) and 8 (c) years after outplanting in a logged over dipterocarp forest in Bislig, Surigao City, Mindanao island, Philippines. Bars represent LSD value at $p<0.05$.

seedling survival.

\subsection{Seedling Growth under Field Conditions}

Two years after outplanting, height growth was highest in cuttings inoculated with Pisolithus H6394 (Figure 5(a)). Pisolithus H6394 increased height by $20 \%$ over the control, two years after outplanting. However, after another two years, those inoculated with Scleroderma outgrew all the rest of the treated counterpart (Figure 5(b)). Scleroderma D01 increased height by $23 \%$ relative to the uninoculated one. Eight years after outplanting, the Philippine Pisolithus was the only ECM fungi that promoted height of S. contorta (Figure 5(c)). Philippine Pisolithus promoted a $23 \%$ taller height than the control $(453 \mathrm{~cm})$. On the other hand, the Australian inoculated cuttings gave the shortest height eight years after outplanting.

In terms of stem diameter, ECM inoculation did not significantly increase stem diameter two years after outplanting (Figure 6(a)). However, after another two years in the field, Scleroderma D01 treated cuttings outgrew the other ECM inoculated seedlings by $29 \%$ relative to the control (Figure 6(b)). The Philippine Pisolithus gave the lowest stem diameter during the four-year growth (Figure 5(b)), but promoted the highest eight weeks after
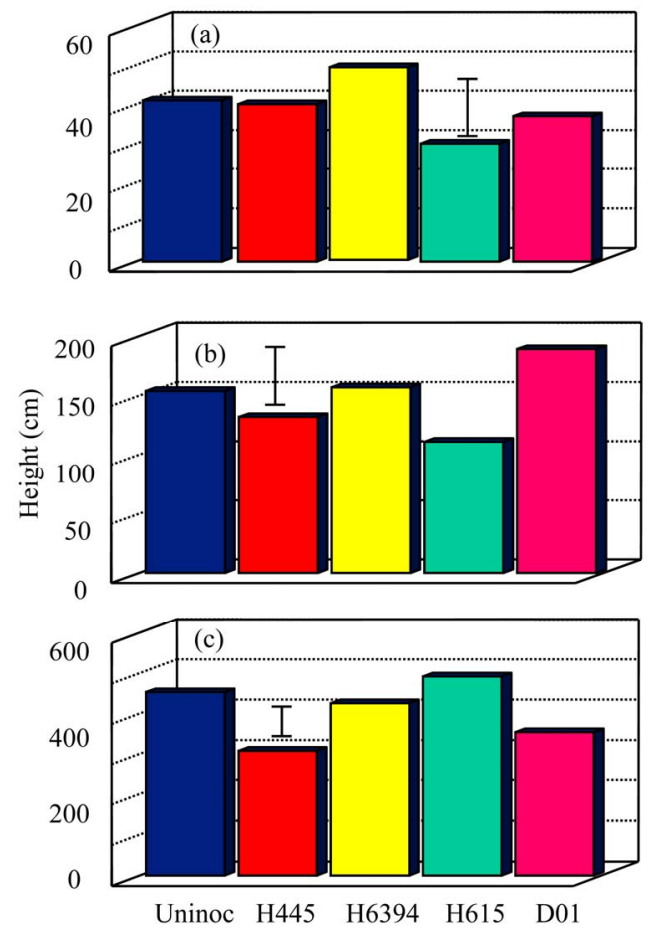

Figure 5. Height of $S$. contorta inoculated with eucalypt and dipterocarp ectomycorrhizal fungi Pisolithus (H445, $\mathrm{H6394}$ and H615) and Scleroderma (D01) isolates 2 (a), 4 (b) and 8 (c) years after outplanting in a logged over dipterocarp forest in Bislig, Surigao City, Mindanao island, Philippines. Bars represent LSD value at $\boldsymbol{p}<0.05$.

planting (Figure 6(c)). This Pisolithus isolate promoted stem diameter of $S$. contorta by $18 \%$.

\subsection{Wood Yield under Field Conditions}

The New Caledonian eucalypt Pisolithus H6394 promoted the highest $\left(10 \mathrm{~cm}^{3}\right)$ wood volume two years after outplanting while those inoculated with the other ECM fungi gave a wood volume lower than the uninoculated ones (Figure 7(a)). Two years later, wood volume obtained by those inoculated with the Australian Pisolithus was lower $\left(74 \mathrm{~cm}^{3}\right)$ than the uninoculated ones $\left(83 \mathrm{~cm}^{3}\right)$ and those inoculated with Scleroderma gave the highest $\left(164 \mathrm{~cm}^{3}\right)$. Scleroderma doubled the wood volume obtained by the control plants (Figure 7(b)) whereas, plants with the Philippine Pisolithus gave the lowest $\left(35 \mathrm{~cm}^{3}\right)$. Eight years after outplanting, the Philippine Pisolithus isolate was the only ECM that promoted wood volume. This local eucalypt isolate increased wood volume by $88 \%$ relative to the control $\left(1829 \mathrm{~cm}^{3}\right)$ (Figure 6(c)).

\section{Discussion}

The potential for improved establishment of dipterocarp seedlings or cuttings with the inoculation with ECM 

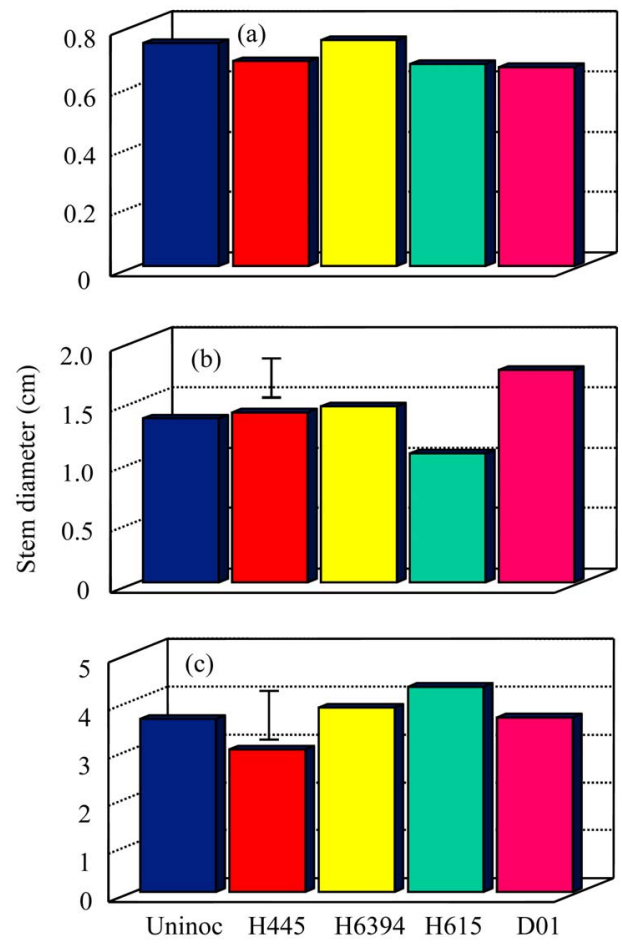

Figure 6. Stem diameter of $S$. contorta inoculated with eucalypt and dipterocarp ectomycorrhizal fungi Pisolithus (H445, H6394 and H615) and Scleroderma (D01) isolates 2 (a), 4 (b) and 8 (c) years after outplanting in a logged over dipterocarp forest in Bislig, Surigao City, Mindanao island, Philippines. Bars represent LSD value at $p<0.05$.

fungi has been demonstrated for several species [16,3944]. Survival of dipterocarp seedlings was proven to be more dependent on ECM association than on light intensity and soil properties [45]. In this study, the four ECM fungi studied differentially influenced growth response of $S$. contorta under nursery and field conditions. Plants inoculated with the exotic eucalypt Pisolithus H445 was the best in promoting growth, robust vegetative growth with larger leaf area and greener in color as compared with the other plants treated with the other exotic eucalypt Pisolithus (H6394) isolate and the native eucalypt Pisolithus (H615) and dipterocarp Scleroderma (D01) isolates. In an earlier study, it was concluded that, the exotic eucalypt Pisolithus H6394 isolate and native dipterocarp Astraeus isolate can be used to inoculate Anisoptera thurifera. Furthermore, Pisolithus H6394 can also be used for $S$. guiso rooted cuttings grown in Philippine red soil and under screenhouse conditions [44]. Growth of Hopea odorata and Hopea helferi was also reported to be stimulated by inoculation with an ECM strain of Pisolithus tinctorius under aseptic conditions [40]. This implies that Hopea odorata and Hopea helferi seedlings respond to ECM infection, and exhibit a low level of host-fungus specificity $[24,40]$.
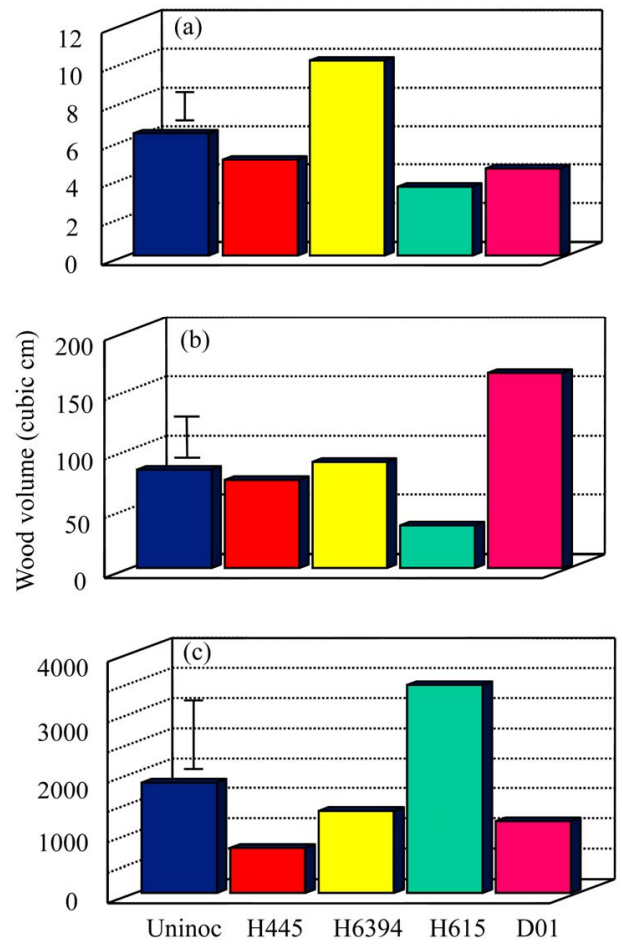

Figure 7. Wood volume of $S$. contorta inoculated with eucalypt and dipterocarp ectomycorrhizal fungi Pisolithus (H445, H6394 and H615) and Scleroderma (D01) isolates 2 (a), 4 (b) and 8 (c) years after outplanting in a logged-over dipterocarp forest in Bislig, Surigao City, Mindano Island, Philippines. Bars represent LSD value at $\boldsymbol{p}<0.05$.

Inocula isolated from one tree species can be successfully inoculated into other species and even genera, leading to improved mineral nutrition and drought tolerance [43]. The Australian eucalypt Pisolithus H445 was introduced in the Philippines in 1992 by the senior author. This fungus promoted the growth of Eucalyptus urophylla grown in the nursery and in marginal grassland in Malaybalay, Bukidnon, Mindanao [46]. The plant growth promoting effect was evident even up to five years after outplanting [22]. However, this fungus never produced fruiting bodies in spite of the presence of infection in the roots [22]. In the present study, Pisolithus H445 was the most promising ECM fungus during the first two years of S. contorta outplanted in a logged-over dipterocarp forest in Bislig, Surigao Sur, Mindanao. Thus implies that this fungus is a good potential inoculant for S. contorta at least during early seedling stage.

At two years, the uninoculated cuttings outgrew those inoculated with a Scleroderma isolate from dipterocarp (DO1), the Pisolithus from New Caledonia (H6394) and also the Philippine Pisolithus (H615). It is possible that the uninoculated plants were colonized with growth promoting indigenous ECM fungi present in the site. The experimental site is a logged over secondary dipterocarp 
forests so, definitely there are indigenous ECM fungi associated with the remaining dipterocarp trees. Fruiting bodies of ECM fungi were observed in the nursery and the adjacent dipterocarp forests about fifty meters away from the experimental site during planting. ECM fungi were different species of Scleroderma and ectomycorrhizal mushrooms. Moreover, since the seedlings were made to acclimatize in the nursery for one month, the seedlings were possibly contaminated with spores from the nursery.

The Australian eucalypt Pisolithus H445 was the most promising ECM isolate at two years. However, growth and yield of $S$. contorta due to inoculation with this fungus was lower than the control during the four and eight year observation period. This implies that this fungus may not have persisted in a logged over dipterocarp forest after two years. The root samples collected eight years after outplanting were not colonized with ECM fungi. Scleroderma species from a dipterocarp forest in Zambales doubled the wood volume in relation to the uninoculated ones at four years but it was no longer effective at eight years. The Philippine Pisolithus from eucalypt forests was less effective in promoting growth and yield during early seedling stages. However, eight years after outplanting, the Philippine Pisolithus isolate promoted the highest height increment and the roots have distinct brilliant golden yellow color. This indicates that, the indigenous Pisolithus, which was collected from eucalypts, survived in the roots of $S$. contorta for eight years even though the growth promoting effects during the early seedling stage was not so prominent.

A similar study was conducted by [47] where an exotic strain of Pisolithus was inoculated into two dipterocarp species. They found that although inoculation enhanced the growth of the dipterocarps, the performance and persistence of the inoculum in logged-over forest was not successful. Kikuchi examined the role of mycorrhizas of dipterocarp seedlings in plantation and in forests by quantification of mycorrhizas [48]. He found that seedlings of 2 to $4 \mathrm{~m}$ high have numerous mycorrhizas and that the amount of mycorrhizas increased as the seedlings became bigger both in plantation and in natural regeneration forests. Abundant mycorrhizas were found in big seedlings. In the present study, it seems that only those inoculated with the Philippine Pisolithus H615 isolate had few (10\% to $15 \%)$ mycorrhizas (but no fruiting bodies) and gave the highest wood yield eight years after outplanting. The other ECM inoculated plants did not have any mycorrhizal roots in spite of the presence of fruit bodies of Scleroderma (S. columnare) in the nearby plantations and nursery. The thick organic matter on the soil surface may have prevented the formation of fruit bodies. Basidiomes of Sclerodermas in the nearby plan- tations were observed in areas with no or very little soil covering.

In conclusion, the results indicate that Pisolithus H445 from eucalypts growing in Australia was the most effective in promoting growth and wood yield of $S$. contorta two years after out planting in a logged over dipterocarp forest in Bislig, Surigao Sur. Scleroderma D01 from dipterocarp forest in the Philippines was the most effective in promoting growth and wood yield at four years after out planting while Pisolithus from the eucalypt plantations in the Philippines was the most effective in promoting growth and wood yield of $S$. contorta eight years after out planting in a logged over dipterocarp forest. It is therefore recommended, that Pisolithus H445, Scleroderma D01 and Pisolithus H615 can be mass produced to address growth promotion of $S$. contorta under nursery and field conditions such as those in logged-over dipterocarp forests in Bislig, Surigao City in the island of Mindanao, Philippines. Moreover, it is important to isolate ectomycorrhiza inoculum that persists on dipterocarps and show signs of improving seedling growth and survival in the early stages of establishment.

\section{Acknowledgements}

This project was partly and jointly funded by the INCODC; International Cooperation with Developing Countries Contract \# ERBIC18CT-98319 entitled "Harnessing mycorrhizal symbiosis in mixed Acacia mangium and dipterocarp plantations in Malaysia and in the Philippines"; National Institute of Molecular Biology and Biotechnology, University of the Philippines Los Banos and the Department of Environment and Natural Resources, Caraga Region, Butuan City, Mindanao island, Philippines.

\section{REFERENCES}

[1] C. J. Kettle, "Ecological Considerations for Using Dipterocarps for Restoration of Lowland Rainforest in Southeast Asia," Biodiversity and Conservation, Vol. 19, No. 4, 2010, pp. 1137-1151. doi:10.1007/s10531-009-9772-6

[2] P. S. Ashton, “Dipterocarpaceae," In: E. Soepadmo, L. G. Saw and R. C. K. Chung, Eds., Tree Flora of Sabah and Sarawak, Vol. 5, Government of Malaysia, Kuala Lumpur, 2005, pp. 63-288

[3] http://en.wikipedia.org/wiki/Dipterocarpaceae

[4] W. T. M. Smits, "Dipterocarpaceae: Mycorrhizae and Regeneration," Tropenbos Series 9, The Tropenbos Foundation, Wageningen, 1994, p. 243.

[5] M. Ogawa, "Mycorrhiza of Dipterocarps," Seminar and Full-Workshop on BIO-REFOR Project, Forestry and Forest Products Research Institute, Ibaraki, Japan, 1992.

[6] S. S. Lee, I. J. Alexander and R. Watling, "Ectomycorrhizas and Putative Ectomycorrhizal Fungi of Shorea 
leprosula Miq. (Dipterocarpaceae)," Mycorrhiza, Vol. 7, No. 2, 1997, pp. 63-81. doi:10.1007/s005720050165

[7] S. S. Lee, "Mycorrhizal Research in Malaysian Plantation Forestry," In: K. Suzuki, K. Ishii, S. Sakurai and S. Sasaki, Eds., Plantation Technology in Tropical Forest Science, Springer, Tokyo, 2006, pp. 157-166. doi:10.1007/4-431-28054-5 15

[8] L. Tedersoo, K. Hanse, B. A. Perry and R. Kjøller, "Molecular and Morphological Diversity of Pezizalean Ectomycorrhiza," New Phytologist, Vol. 170, No. 3, 2006, pp. 581-596. doi:10.1111/j.1469-8137.2006.01678.x

[9] S. E. Smith and D. J. Read, "Mycorrhizal Symbiosis," 2nd Edition, Academic Press, San Diego, 1997.

[10] J. Whitfield, "Fungal Roles in Soil Ecology: Underground Networking,” Nature, Vol. 449, No. 7159, 2007, pp. 136138. doi:10.1038/449136a

[11] W. T. M. Smits, "Dipterocarps and Mycorrhiza. An Ecological Adaptation and Factors in Forest Regeneration," Flora Malesiana Bulletin, Vol. 36, 1983, pp. 3926-3937.

[12] N. M. Pampolina, R. E. De la Cruz and M. U. Garcia, "Ectomycorrhizal Roots and Fungi of Philippine Dipterocarps," In: M. Brundrett, B. Dell, N. Malajczuk and M. Gong, Eds., Mycorrhizal Research for Forestry in Asia, ACIAR Proceedings, Canberra, 1996, pp. 47-50.

[13] T. Watling and S. S. Lee, "Ectomycorrhizal Fungi Associated with Members of the Dipterocarpaceae in Peninsular Malaysia," Journal of Tropical Forest Science, Vol. 7, 1995, pp. 657-669.

[14] K. Sims, R. Watling, R. E. de la Cruz and P. Jeffries, "Ectomycorrhizal Fungi of the Philippines: A Preliminary Survey and Notes on the Geographic Biodiversity of the Sclerodermatales," Biodiverstiy \& Conservation, Vol. 6, No. 1, 1997, pp. 45-58. doi:10.1023/A:1018371515051

[15] N. S. Aggangan and E. B. Lorilla, "Development of Ectomycorrhizal Inoculants for Eucalyptus and Dipterocarps," Terminal Report UPLB-Basic Research Program, UPLB, Los Baños, 2000, p. 52

[16] M. M. D. Tennakoon, I. A. U. N. Gunatilleke, K. M. Hafeel, G. Seneviratne, V. V. S. Gunatilleke and P. M. S. Ashton, "Ectomychorrhizal Colonization and Seedling Growth of Shorea (Dipterocarpaceae) Species in Simulated Shade Environments of a Sri Lankan Rain Forest," Forest Ecology and Management, Vol. 208, No. 1-3, 2005, pp. 399-405. doi:10.1016/j.foreco.2004.12.010

[17] M. Turjaman, Y. Tamai, H. Segah, S. H. Limin, J. Y. Cha M. Osaka and K. Tawaraya, "Increase in an Early Growth and Nutrient Uptake of Shorea seminis Seedlings Inoculated with Two Ectomycorrhizal Fungi," Journal of Tropical Forest Science, Vol. 18, No. 4, 2006, pp. 243-249.

[18] M. Turjaman, M. Saito, E. Santoso, A. Susanto, S. Gaman, S. H. Limin, M. Shibuya, K. Takahashi, Y. Tamai, M. Osaki and K. Tawaraya, "Effect of Ectomycorrhizal Fungi Inoculated on Shorea balangeran under Field Conditions in Peat-Swamp Forests," In: J. O. Rieley, C. J. Banks and B. Radjagukguk, Eds., Carbon-Climate-Human Interaction on Tropical Peatland, Proceedings of the International Symposium and Workshop on Tropical Peatland, Yogyakarta, 27-29 August 2007, pp. 27-29. http://www.geog.le.ac.uk/carbopeat/yogyaproc.html

[19] P. Machon, O. Santamaria, J. A. Pajares, F. M. AlvesSantos and J. J. Diez, "Influence of the Ectomycorrhizal Fungus Laccaria laccata on Pre-Emergence, Post-Emergence and Late Damping-Off by Fusarium moniliforme and F. oxysporum on Scots Pine Seedlings," Symbiosis, Vol. 42, 2006, pp. 153-160.

[20] J. L. Parke, R. G. Linderman and C. H. Black, "The Role of Ectomycorrhizas in Drought Tolerance of Douglas-Fir Seedlings," New Phytologist, Vol. 95, No. 1, 1983, pp. 83-95. doi:10.1111/j.1469-8137.1983.tb03471.x

[21] R. E. De la Cruz, E. B. Lorilla and N. S. Aggangan, "Ectomycorrhizal Tablets for Eucalyptus Species," In: D. Werner and P. Muller, Eds., Fast Growing Trees and Nitrogen Fixing Trees, Gustav Fisher Verlag, Stuttgart, 1990, p. 371.

[22] N. S. Aggangan, B. Dell, N. Malajczuk and R. E. De la Cruz, "Growth and Wood Yield of Eucalyptus urophylla S.T. Blake Inoculated with an Australian and a Philippine Isolates of Pisolithus in Three Grasslands in the Philippines," Sylvatrop: The Technical Journal of Philippine Ecosystems and Natural Resources, Vol. 9, No. 1, 1999, pp. 19-22.

[23] C. M. Tonkin, N. Malajczuk and J. A. McComb, "Ectomycorrhizal Formation by Micropropagated Clones of Eucalyptus marginata Inoculated with Isolates of $\mathrm{Pi}$ solithus tinctorius," New Phytologist, Vol. 111, No. 2, 1989 , pp. 209-214.

doi:10.1111/j.1469-8137.1989.tb00684.x

[24] R. Molina, H. Massicotte and J. M. Trappe, "Specificity Phenomena in Mycorrhizal Symbioses: CommunityEcological Consequences and Practical Implications," In: M. J. Allen, Ed., Mycorrhizal Functioning an Integrative Plant-Fungal Process, Chapman and Hall, New York, 1992, pp. 357-423.

[25] N. Malajczuk, R. Molina and J. Trappe, "Ectomycorrhizal Formation in Eucalyptus I. Pure Culture Synthesis, Host Specificity and Mycorrhizal Compatibility with Pinus radiata," New Phytologist, Vol. 91, No. 3, 1982, pp. 467482. doi:10.1111/j.1469-8137.1982.tb03325.x

[26] P. Becker, "Ectomycorrhizae on Shorea Seedlings in a Lowland Malaysian Rainforest," Malaysian Forester, Vol. 46, 1983, pp. 146-170.

[27] F. Martin, J. Diez, B. Dell and C. Delaruelle, "Phylogeography of the Ectomycorrhizal Pisolithus Species as Inferred from Nuclear Ribosomal DNA ITS Sequences," New Phytologist, Vol. 153, No. 2, 2002, pp. 345-357. doi:10.1046/j.0028-646X.2001.00313.x

[28] J. Kanchanaprayudh, Z. Zhou, S. Yomyart, P. Sihanonth and T. Hogetsu, "Molecular Phylogeny of Ectomycorrhizal Pisolithus Fungi Associated with Pine, Dipterocarp, and Eucalyptus Trees in Thailand," Mycoscience, Vol. 44, No. 4, 2003, pp. 287-294. doi:10.1007/s10267-003-0110-7

[29] M. S. Reddy, S. Singla, K. Natarajan and G. Senthilarasu, "Pisolithus indicus, a New Species of Ectomycorrhizal Fungus Associated with Dipterocarps in India," Mycologia, Vol. 97, No. 4, 2005, pp. 838-843. 


\section{doi: $10.3852 /$ mycologia. 97.4 .838}

[30] M. T. Pollisco, "Some Developments on Dipterocarp Propagation Research in the Philippines," In: U. Sangwanit, et al., Eds., Proceedings of International Workshop BIO-REFOR, Bangkok, 1997, pp. 34-44.

[31] M. T. Pollisco, "Developments in Dipterocarp Propagation Research in the Philippines," In: K. Suzuki, K. Ishii, S. Sakurai and S. Sasaki, Eds., Plantation Technology in Tropical Forest Science, Springer, Tokyo, 2006, pp. 207210. doi:10.1007/4-431-28054-5_9

[32] D. H. Marx, "The Influence of Ectotrophic Mycorrhizal Fungi on the Resistance of Pine Roots to Pathogenic Infection I. Antagonism of Mycorrhizal Fungi to Root Pathogenic Fungi and Soil Bacteria," Phytopathologist, Vol. 59, 1969, pp. 153-163.

[33] N. S. Aggangan, B. Dell, N. Malajczuk and R. E. de la Cruz, "Field Performance of Eucalyptus urophylla Inoculated with Introduced and Indigenous Strains of Ectomycorrhizal Fungus Pisolithus," Sylvatrop: The Technical Journal of Philippine Ecosystems and Natural Resources, Vol. 9, No. 1, 1999, pp. 29-42.

[34] M. Brundrett, N. L. Bougher, B. Dell, T. Grove and N. Malajczuk, "Working with Mycorrhizas in Forestry and Agriculture," ACIAR Monograph, Vol. 32, 1996, p. 374.

[35] E. I. Newman, "A Method of Estimating the Total Length of Root in a Sample," Journal of Applied Ecology, Vol. 3, No. 1, 1966, 139-145. doi:10.2307/2401670

[36] K. A. Gomez and A. A. Gomez, "Statistical Procedures for Agriculture Research," 2nd Edition, John Wiley and Sons, Inc., New York, 1984.

[37] D. B. Duncan, "Multiple Range and Multiple F Tests," Biometrics, Vol. 11, No. 1, 1955, pp. 1-24. doi: $10.2307 / 3001478$

[38] Michigan State University, "User's Guide to MSTAT-C. Design, Management and Statistical Research Tool," Michigan State University, East Lansing, 1989, 152 p.

[39] Supriyanto, I. Setiawan and R. M. Omon, "Effect of Scleroderma sp. on the Growth of Shorea mecistopteryx Ridi Seedlings," In: K Suzuki, S. Sakurai and I. Ishii, Eds., Proceedings of the International Workshop of BIOREFOR, Yogyakarta, 20-23 September 1993, pp. 186188.

[40] M. S. Yazid, S. S. Lee and F. Lapeyrie, "Growth Stimulation of Hopea spp. (Dipterocarpaceae) Seedlings Follow- ing Ectomycorrhizal Inoculation with an Exotic Strain of Pisolithus tinctorius," Forest Ecology and Management, Vol. 67, No. 1-3, 1994, pp. 339-343. doi:10.1016/0378-1127(94)90028-0

[41] M. Turjaman, Y. Tamai, H. Segah, S. H. Limin, J. Y. Cha, M. Osaka and K. Tawaraya, "Inoculation with the Ectomycorrhizal Fungi Pisolithus arhizus and Scleroderma sp. Improves Early Growth of Shorea pinanga Nursery Seedlings," New Forests, Vol. 30, No. 1, 2005, pp. 67-73. doi:10.1007/s11056-004-1954-1

[42] Suhardi, E. Faridah, E. Iskandar and S. Rahayu, "Mycorrhizal Formation and Growth of Shorea leprosula in Bukit Suharto after Using Charcoal and Rockphosphate," In: K. Suzuki, K. Ishii, S. Sakurai and S. Sasaki, Eds., Plantation Technology in Tropical Forest Science, Springer, Tokyo, 2006, pp. 175-183.

[43] S. S. Lee, M. Patahayah, W. S. Chong and F. Lapeyrie, "Successful Ectomycorrhizal Inoculation of Two Dipterocarp Species with a Locally Isolated Fungus in Peninsular Malaysia," Journal of Tropical Forest Science, Vol. 20, 2008, pp. 237-247.

[44] N. S. Aggangan, J. S. Aggangan, J. C. O. Bulan and C. A. S. Limos, "Inoculation of Dipterocarps Anisoptera thurifera and Shorea guiso with Ectomycorrhizal Fungi in Philippine Red Soil," Philippine Journal of Science, Vol. 141, No. 2, 2012, pp. 229-241.

[45] I. Yasman, "Dipterocarpaceae: Tree-Mycorrhizae-Seedling Connections," Ph.D. Thesis, Wageningen Agricultural University, The Netherlands, 1995.

[46] N. S. Aggangan, "Soil Factors Affecting the Formation and Function of Pisolithus-Eucalyptus urophylla Ectomycorrhizas in Acid Soils in the Philippines," Ph.D. Thesis, Murdoch University, Perth, 1996.

[47] Y. S. Chang, S. S. Lee, F. Lapeyrie and M. S. Sanip. "Competitiveness of Two Strains of Pisolithus tinctorius on Seedlings of Three Dipterocarp Species under Nursery and Field Conditions," In: K. Suzuki, K. Ishii, S. Sakurai and S. Sasaki, Eds., Plantation Technology in Tropical Forest Science, Springer, Tokyo, 2006, pp. 199-206.

[48] J. Kikuchi, "Ectomycorrhizas of Dipterocarps in the Logged over Forests and Plantations," In: K. Suzuki, K. Ishii, S. Sakurai and S. Sasaki, Eds., Plantation Technology in Tropical Forest Science, Springer, Tokyo, 2006, pp. $207-210$. 